\title{
Analysis of chemical stability of tap water in terms of required level of technological safety
}

\author{
Katarzyna Pietrucha-Urbanik ${ }^{1 *}$, Barbara Tchórzewska-Cieślak ${ }^{1}$, Dorota Papciak², \\ Izabela Skrzypczak ${ }^{3}$
}

\author{
Rzeszow University of Technology \\ Faculty of Civil, Environmental Engineering and Architecture \\ ${ }^{1}$ Department of Water Supply and Sewerage Systems \\ ${ }^{2}$ Department of Water Purification and Protection \\ ${ }^{3}$ Department of Geodesy and Geotechnics
}

*Corresponding author's e-mail: kpiet@prz.edu.pl

Keywords: chemical stability of water, corrosion indices, technological safety, risk criteria.

\begin{abstract}
The main goal of this work is to show the new approach to determining safety technological levels (SLs) in terms of water quality and its chemical stability, as well as issues of water corrosion properties in water distribution systems (WDSs), due to the fact that water supply pipes are prone to corrosion. In the paper the methodology of determining the risk associated with threat to technical infrastructure was considered. The concept was studied on the basis of real operational data from the water treatment plant. The probability of exceeding the individual parameters for WTPI is slightly larger than for WTPII, which means that this water treatment process may cause lack of chemical stability in the water supply network. Operators should anticipate in the process of designing water distribution system, using proper materials, as to ensure an adequate level of safety from the water source to the water recipient. It should be noted that it is necessary to adjust the material of internal installation of water supply networks to the parameters of the water. At present, there are no correlations between the designing step and water parameters. It was concluded that to protect the water supply infrastructure, which belongs to critical infrastructure, water company should put more emphasis on distribution of stable water that has not potentially corrosion properties. Some suggestions were made for the protection of WDS and to ensure safety of system functioning and long-term usability of water pipes.
\end{abstract}

\section{Introduction}

The water quality in water distribution system is an important issue, concerning the proper operation of water pipes, as well as influencing the life and health of water consumers (Tchorzewska-Cieslak and Rak 2010). Therefore numerous studies and research were conducted, taking into account the disinfection influence on biofilm along with corrosion of cast iron pipes, e.g. (Gerke et al. 2008, Husband and Boxall 2011, McNeill and Edwards 2001, Zhang et al. 2015). Many publications, e.g. (Dubiel et al. 2002, Haibo et al. 2015, Lia et al. 2014, Volk et al. 2000, Zhang et al. 2010), indicate strong dependence between biofilm on network metal pipe and its protective barrier against corrosion (Gorka et al. 2008). Providing balance of calcium carbonate and therefore chemical stability of water is necessary for the proper functioning of the water supply network (Nowacka et al. 2016, TchórzewskaCieślak and Szpak 2012, Pietrzyk and Papciak 2016). Chemical instability of tap water contributes to the secondary contamination of water. In such situation water supplied to customers can meet the requirements of the standard, but it is of lower quality than water flowing into the water supply network (Carneiro et al. 2015, Ferrandez-Gamot et al. 2015, Kutylowska and Orlowska-Szostak 2016). The main reason for the lack of chemical stability is water aggressiveness and corrosiveness, the intensity of which depends on the water chemistry and the method of its purification (Kiedryńska et al. 2006, Ondrejka-Harbulakova et al. 2015). Water is defined as chemically stable when it does not change the composition and does not cause the destruction of the materials with which it is in contact. There are many factors that cause corrosion in water distribution systems. Some of them can be as following: characteristics of metal material (chemical composition and microstructure, the state of the surface composition), physico-chemical composition of water (e.g. temperature, $\mathrm{pH}$, conductivity, total and calcium hardness, alkalinity, acidity, dissolved oxygen, chloride ions, nitrate ions, sulphate ions), water distribution systems design and construction (geometry, systems consisting of different metals, connections, tensile stress), pressure test and commissioning (flushing of water stream, water drainage, decontamination, rinsing), operating conditions of the system (temperature, flow conditions, decontamination). An important step in the process of corrosion inhibition is the formation of protective 
layers which arise in appropriate conditions and are likely to prevent the corrosion process. Electrochemical methods of protecting cold water installation do not provide a complete elimination of the corrosion threat; the main reason for such situation is that these methods involve periodic monitoring and are difficult to conduct in real operational conditions. According to the standard (EN 12502-2006) corrosion is the result of the interaction between various factors, its size can only be expressed in the risk category of the corrosive damage. Including these assumptions in the presented study the corrosion problem was considered in terms of risk category. Many conducted studies and performed research indicate the strong dependence between water quality and corrosion process together with the material structure of water pipe. Also important issue is implementation of methods for assessing risk of failure in critical infrastructure systems (Królikowska 2011), health risk assessment (Garboś and Święcicka 2015), water indices (Darvishi et al. 2016) or through preventive maintenance process (Studziński and Pietrucha-Urbanik 2015) and cost incurred as a result of failure (Tchorzewska-Cieslak et al. 2012). As well as implementation of mathematical modelling in environmental engineering (Kaźmierczak and Wdowikowski 2016), unitarization method (Radzka et al. 2015) and analysis of pollution source in water environment (Suna et al. 2016) constitute the important issue in providing safe water to its consumers. The Monte Carlo simulation used in the presented methodology widely contributes to assess technological safety, what confirms the necessity of using these methods to evaluate the functioning of communal infrastructure (Tchórzewska-Cieślak et al. 2016).

In numerous existing and operating water supply systems it is forbidden to use galvanized steel due to the corrosive properties of treated water. Taking into consideration all the presented problems occurring in water network, the objective of this paper is to indicate the dependence between the conditions of water treatment and water quality in water distribution system. In this paper the hazards associated with the chemical stability of water in water distribution subsystem were analyzed.

\section{The definition of technological safety}

Technological safety (TS) is defined as the ability of the treatment process to avoid hazards, which may result in not meeting the quality parameters of treated water, what can cause a real threat to the health of water consumers. Hazards can be a result of undesirable events, which occur in the water intake, during the process of water treatment or water distribution. The measure of the loss of technological safety is the risk associated with not meeting certain water quality parameters, which may have a negative impact on the physical and chemical parameters of water supplied to the consumers. Risk is defined as the expected value of losses (consequences) that may occur as a result of exceeding the specified parameters of water quality. Proceeding from the definition of the expected value so defined risk is determined as the probability of exceeding the assumed parameters of water quality.

In this regard, we distinguish:

- risk associated with the direct threat to consumers health (the so called health risk $R_{H}$ ). The risk is related to the exceeding of water quality parameters which are direct threat to the consumers lives or health.
- risk associated with threats to the technical infrastructure (the so called technical risk $\mathrm{R}_{\mathrm{T}}$ ). This risk is related to the exceeding of water quality parameters that directly negatively influence the technical condition of water supply infrastructure but indirectly may be the cause of serious health problems, an example of such threats can be corrosive water, which will cause corrosion of materials of water supply network, which results in pitting, multiply ferruginous bacteria, which in turn promotes the formation of the so-called biofilm in the network. Under unfavourable hydraulic conditions such sequence of events may cause the so-called secondary water pollution in the water supply network, e.g. the deterioration of organoleptic parameters but also the presence of pathogenic microorganisms, resulting in loss of human life or health.

In safety theory such sequence of events is called the domino effect, in which the so called initiating event has no direct impact on the loss of safety, as a result of the subsequent events can lead to serious consequences.

The work concerns the analysis and assessment of the risk of losing the chemical stability of water. The consequences are the increased susceptibility to corrosion and secondary deterioration of organoleptic parameters through secondary pollution of water in the network, and thus threat to consumers' health.

\section{Assessment of the aggressive and corrosive properties of water}

Unstable water causes overgrowth of deposits of calcium carbonate in water pipes and contributes to corrosion of deposits. Corrosion destroys water pipes and contaminates them with corrosion products.

There are many parameters which determine the corrosive properties of water, among them are those related to the state of calcium-carbonate equilibrium: the Langelier saturation Index $\left(I_{L}\right)$, the Ryznar Index $\left(I_{R}\right)$ and the Strohecker Index $\left(I_{s t}\right)$.

Although for the assessment of water corrosiveness the numerous indices are used, due to the complexity of the corrosion process, none of them provides a complete assessment of the rate of corrosion in aquatic environment.

The Langelier Index can be calculated according to such water quality indicators as $\mathrm{pH}$, dry residue, temperature, alkalinity and calcium content from the formula (1) (Langelier 1936):

$$
I_{L}=p H_{0}-p H_{S}
$$

where $I_{L}$ is the Saturation Index, $p H_{0}-p H$ of the examined water sample, $p H_{s}-p H$ in saturated state.

If:

- $I_{L}<0$ - water has the ability to dissolve calcium compounds and its corrosion properties are enhanced,

- $I_{L}=0$-water is stable, i.e., it does not tend to precipitate or dissolve calcium carbonate, the corrosion properties are weakened (in further considerations it was assumed that for acceptable safety level $I_{L}$ is in the range from -0.5 to 0.5$)$,

- $I_{L}>0$ - water has the ability to precipitate lime and its corrosion properties are weakened. 
Waters having the positive Langelier Index, low oxygen content and the total content of chloride and sulfate ions of less than $50 \mathrm{mg} / \mathrm{dm}^{3}$ are considered to be non-corrosive.

The tendency of water to form protective layers is better defined by the Ryznar Index $I_{R}$, determined from the formula (2) developed by (Ryznar 1944):

$$
I_{R}=2 p H_{s}-p H_{0}
$$

Corrosiveness of water can be determined also on the basis of the Strohecker formulas (3, 4) (Strohecker 1936). This indicator is often used by the water treatment plants to assess water corrosive properties:

$$
I_{s t}=p H_{n}-p H_{0}
$$

wherein:

$$
p H_{N}=11.39-2 \lg A
$$

where $I_{s t}$ is the stability indicator, $p H_{n}-p H$ value corresponding to carbonate-calcium equilibrium, for such water that is in equilibrium with the solid $\mathrm{CaCO}_{3}, \mathrm{pH}_{0}-\mathrm{pH}$ of the examined water, $A$ - the amount of bounded $\mathrm{CO}_{2}, \mathrm{mg} / \mathrm{dm}^{3} \mathrm{CO}_{2}$.

If:

$I_{s t}<0\left(\mathrm{pH}_{\mathrm{n}}<\mathrm{pH}\right)-$ water is non-corrosive, hence it has tendency to $\mathrm{CaCO}_{3}$ precipitation,

$I_{s t}=0\left(\mathrm{pH}_{\mathrm{n}}=\mathrm{pH}\right)-$ water is non-corrosive,
$I_{s t}>0\left(\mathrm{pH}_{\mathrm{n}}>\mathrm{pH}\right)-$ water is corrosive.

The intensity of corrosion depends on the stability Index $I_{s t}$ : $I_{s t}<0.5-$ non aggressive water,

$0.5<I_{s t}<2.0$ - water with average aggressiveness,

$2.0<I_{s t}<4.0-$ aggressive water.

Recommendations for procedure depending on the value of the Langelier Index according to (Carrier Air Conditioning Company 1965) are shown in Table 1.

Properties of water depending on the value of the Ryznar Index with recommendations given by (Carrier Air Conditioning Company 1965) are shown in Table 2.

\section{Risk criteria defining technological safety level of water treatment process}

The following criteria defining the different levels of safety were assumed:

- tolerable risk and acceptable safety level $\left(\mathrm{SL}_{\mathrm{T}}\right)$ - water is chemically stable while keeping the following parameters:

the Langelier saturation Index $-I_{L}=$ from -0.5 to 0.5 ,

or

the Ryznar Index $-I_{R}=6.2-6.8$,

or

the Strohecker Index $-I_{s t}<0.5$,

- controlled risk and safety level, which requires modification $\left(\mathrm{SL}_{\mathrm{RM}}\right)$ - mild corrosion, does not generate

\begin{tabular}{|c|c|c|c|c|c|c|c|c|c|c|c|}
\hline \multicolumn{12}{|c|}{ Value of Langier Index $-I_{L}$} \\
\hline-5 & -4 & -3 & -2 & -1 & -0.5 & 0 & 0.5 & 1 & 2 & 3 & 4 \\
\hline \multicolumn{12}{|c|}{ Corrosion intensity } \\
\hline $\begin{array}{l}\frac{c}{0} \\
\frac{0}{0} \\
\stackrel{0}{0} \\
0 \\
\frac{0}{0} \\
\frac{0}{0} \\
\frac{0}{\square}\end{array}$ & 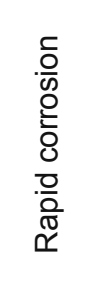 & $\begin{array}{l}\frac{\overline{0}}{0} \\
\frac{0}{0} \\
0 \\
0 \\
0 \\
\frac{0}{\pi} \\
\frac{\pi}{0} \\
\frac{0}{0} \\
\frac{0}{2}\end{array}$ & 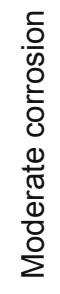 & 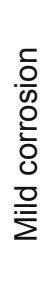 & 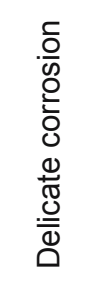 & $\begin{array}{l}0 \\
0 \\
\frac{E}{0} \\
\frac{\pi}{0} \\
0 \\
0 \\
0 \\
\frac{0}{0} \\
0 \\
0 \\
\frac{0}{\pi} \\
0\end{array}$ & 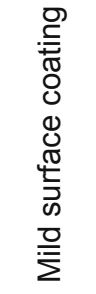 & 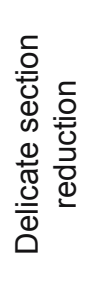 & 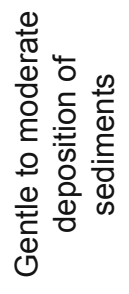 & 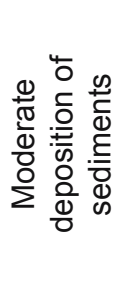 & 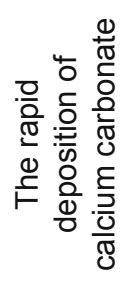 \\
\hline \multicolumn{12}{|c|}{ Recommendations } \\
\hline 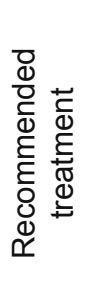 & 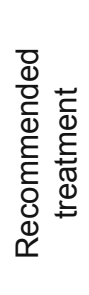 & 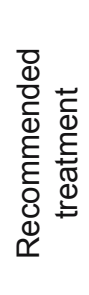 & 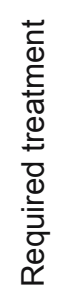 & 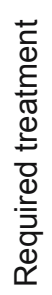 & 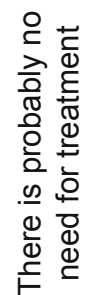 & 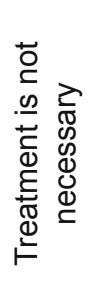 & 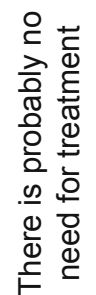 & 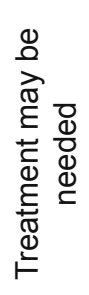 & 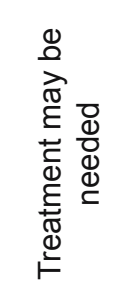 & 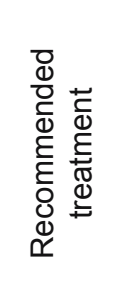 & 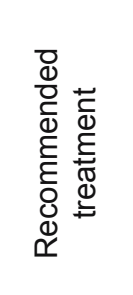 \\
\hline
\end{tabular}

Table 1. Recommendations for procedure depending on the value of the Langelier index according to Carrier Air Conditioning Company

Table 2. Properties of water depending on the value of the Ryznar index

\begin{tabular}{|c|c|c|c|c|}
\hline \multicolumn{5}{|c|}{ Range of $I_{R}$} \\
\hline$I_{R}<5.5$ & $5,5<I_{R}<6.2$ & $6.2<I_{R}<6.8$ & $6.8<I_{R}<8.5$ & $I_{R}>8.5$ \\
\hline \multicolumn{5}{|c|}{ Original indication of Ryznar } \\
\hline Thick incrustation & Creating incrustation & $\begin{array}{c}\text { Without operational } \\
\text { difficulties }\end{array}$ & $\begin{array}{c}\text { Water with tendency to } \\
\text { dissolve deposits }\end{array}$ & Aggressive water \\
\hline
\end{tabular}


protective coating layers of $\mathrm{CaCO}_{3}$, while keeping the following parameters:

the Langelier Saturation Index $-I_{L}=$ from -2 to 4

or

the Ryznar Index $-I_{R}=$ less than 8.5

or

the Strohecker Index $-I_{s t}>0.5$,

except cases when tolerable risk (for the Langelier saturation Index $-I_{L}=$ from -0.5 to 0.5 and the Ryznar Index $-I_{R}=6.2-6.8$ ) and unacceptable risk (for the Langelier saturation Index $-I_{L}=$ from 3 to 4 and the Ryznar Index $-I_{R}=$ less than 5.5 ) occur,

- unacceptable risk and unacceptable safety level $\left(\mathrm{SL}_{\mathrm{UNA}}\right)$ - violent corrosion, does not generate protective coating layers of $\mathrm{CaCO}_{3}$, while keeping the following parameters:

the Langelier saturation Index $-I_{L}=$ from -3 to -5 , or

the Ryznar Index $-I_{R}=$ more than 8.5 and for less than 5.5,

or

the Strohecker Index $-I_{s t}>0.5$,

or

the Langelier saturation Index $-I_{L}=$ from 3 to 4 , or

the Ryznar Index $-I_{R}=$ less than 5.5,

or

the Strohecker Index $-I_{s t}>0.5$.

To assess the technological safety of the water treatment process the available parameters are taken into account. As to meet the requirement to maintain the specified SL just one parameter of corrosivity is needed and when all the determined parameters are available, the parameter with the most unacceptable value is considered.

Indexes defining the area of tolerated risk suggest that the parameters of the tap water provide the required chemical stability in water distribution system. While the levels of controlled risk mean that water quality parameters indicate the possibility of changes in chemical stability in water distribution system.

Unacceptable risk means that such water quality parameters occur which cause a lack of chemical stability of water in the water supply system, which in turn can cause the secondary pollution.

\section{Characteristics of the analyzed water supply system}

The city is supplied with water from the river using boundary-chamber water intake capacity of 90 thousand $\mathrm{m}^{3} / \mathrm{d}$. The water is treated in modernized Water Treatment Plants WTP $_{I}$ and WTP $_{\text {II }}$ and fulfills the quality requirements for water intended for human consumption.

$\mathrm{WTP}_{\mathrm{I}}$ and $\mathrm{WTP}_{\mathrm{II}}$ are both independent water treatment plants, working on the basis of the same technology. At present, in both plants the same treatment processes are conducted, ie.: preliminary ozonation, coagulation supported by synthetic flocculant (when low temperatures occur), sedimentation in septic horizontal, filtration on rapid filter. In the $\mathrm{WTP}_{\mathrm{I}}$ sand filters are used whereas on the $\mathrm{WTP}_{\text {II }}$ anthracite-sand filters, ozonation and indirect carbon filters BAF are used. The chambers of intermediate ozonation are completely separated from $\mathrm{WTP}_{\mathrm{I}}$ and $\mathrm{WTP}_{\mathrm{II}}$. The water after the ozonation gets to four chambers of carbon filters and from there to water tanks of $\mathrm{WTP}_{\mathrm{I}}$ and $\mathrm{WTP}_{\mathrm{II}}$.

Average daily production of treated water is about 37 thousand $\mathrm{m}^{3} / \mathrm{d}$, in fully supplying the water recipients. In operation of water company in the distinguished water supply systems there are also emergency deep-seated intake with the capacity of $260 \mathrm{~m}^{3} / \mathrm{d}$, local water intake with the capacity of $450 \mathrm{~m}^{3} / \mathrm{d}$, 36 water pumping stations, 11 expansion tanks of clean water with a total capacity of 35 thousand $\mathrm{m}^{3}$ and 190 public wells.

A total length of the water supply network is approx. $890 \mathrm{~km}$ of $50 \mathrm{~km}$ of main network, distributional pipes about $470 \mathrm{~km}$ and $350 \mathrm{~km}$ of water connections. The main network is made of cast iron and steel pipes. Distributional pipes are made of cast iron, galvanized steel, PE and PVC and water connections are mainly made of galvanized steel, cast iron PE and PVC.

Water supply network consists of four mains transporting treated water from second pumping station:

- $1^{\text {st }}$ main ( $\varphi$ 1200, $\varphi$ 1000, $\left.\varphi 800 \mathrm{~mm}\right)$, which transports water from $\mathrm{WTP}_{\mathrm{II}}$ and supplies the north-western part of the city and clean water tank,

- $2^{\text {nd }}$ main ( $\varphi 400 \mathrm{~mm}$ ) transports water from $\mathrm{WTP}_{I}$ to the center and north of the city, it has two branches, of which one ( $\varphi 200 \mathrm{~mm}$ ) supplies nearby villages, while the second provides water to the city center,

- $3^{\text {rd }}$ main ( $\varphi 400 \mathrm{~mm}$ ) transports water from $\mathrm{WTP}_{\mathrm{II}}$ to the southern and central parts of the city,

- $4^{\text {th }}$ main $(\varphi 400 \mathrm{~mm})$ transports water from $\mathrm{WTP}_{\mathrm{I}}$ and $\mathrm{WTP}_{\mathrm{II}}$ to the eastern and north-eastern parts of the city and supplies tanks; it has two branches $(\varphi 150 \mathrm{~mm}$ and $\varphi 100 \mathrm{~mm}$ ) which supply water to nearby villages.

The network in $80 \%$ works in the ring system, in which water supply system cooperates with two sets of water supply tanks located in the eastern and western parts of the city.

\section{Assessment of water corrosion aggressiveness in the considered water supply system}

The test samples were taken after two sequences of technological water treatment processes $\mathrm{WTP}_{\mathrm{I}}$ and $\mathrm{WTP}_{\mathrm{II}}$.

Langelier Index $\left(I_{L}\right)$, Ryznar Index $\left(I_{R}\right)$ and Strohecker Index values $\left(I_{s t}\right)$ were calculated for the monthly average for 2015 and are shown in Figure 1.

In the examined water supply system, water has the Langelier Index values from -0.5 to $0.12\left(\mathrm{WTP}_{\mathrm{I}}\right)$ and from -0.4 to 0.24 . $\left(\mathrm{WTP}_{\mathrm{II}}\right)$. The range of variation for the Ryznar Index in various technological lines of water treatment was, respectively, $7.2 \leq I_{R} \leq 8.2$ for $\mathrm{WTP}_{\mathrm{I}}$ and $7.2 \leq I_{R} \leq 8.1$ for $\mathrm{WTP}_{\mathrm{II}}$. Similarly, for $\mathrm{WTP}_{\mathrm{I}}$ and $\mathrm{WTP}_{\mathrm{II}}$, the Strohecker stability Index was, respectively, from -0.26 to 0.75 and from -0.36 to 0.78 .

The results, taking into account the Ryznar Index, indicate the occurrence of water with a tendency to dissolve deposits and severity of corrosion processes. In the case of the Strohecker Index we are dealing with non-aggressive water $\left(I_{s t}<0.5\right)$ for $73 \%$ of samples $\left(\mathrm{WTP}_{\mathrm{I}}\right)$ and for $82 \%$ of samples $\left(\mathrm{WTP}_{\mathrm{II}}\right)$. Other water samples correspond to medium aggressiveness, reaching in the examined period the following maximum values: 
$I_{\text {stWTPI }}=0.75$ and in the second case $I_{\text {stWTPII }}=0.78$. The character of water specified by the Langelier Index corresponds to the probable lack of need for additional water treatment and in the majority of tested samples the mild covering of pipes surface in case of corrosion.

Taking into account the aforementioned criteria in Figure 2, the average and median values of the Langelier, Ryznar and Strohecker indices for two technological water treatment processes $\mathrm{WTP}_{\mathrm{I}}$ and $\mathrm{WTP}_{\mathrm{II}}$ were presented.

According to the adopted risk assessment criteria, water quality in the tested system is at the level of controlled risk $R_{c}$.

Water produced by the $\mathrm{WTP}_{\mathrm{I}}$ and $\mathrm{WTP}_{\mathrm{II}}$ in the majority of the tested samples is chemically unstable with tendency to dissolve deposits and the possibility of minor corrosion.

\section{Assessment of technological safety of water chemical stability}

Assessment of technological safety of water chemical stability was performed using two-dimensional method in which the probabilities of the exceeding of the parameters for the assessment of aggressive and corrosive water properties were determined, according to the aforementioned risk definition and criteria.
- for the Langelier Index $-I_{L}(5)$ :

$$
R_{n z}^{I_{L}}=P\left(p H_{0}\left(x_{i}\right)-p H_{s}\left(x_{j}\right)\right)
$$

- for the Ryznar Index $-I_{R}(6)$ :

$$
R_{n z}^{I_{R}}=P\left(2 p H_{s}\left(x_{j}\right)-p H_{0}\left(x_{i}\right)\right)
$$

- for the Strohecker Index $-I_{s t}(7)$ :

$$
R_{n z}{ }^{I_{R}}=P\left((11,39-2 \lg \mathrm{A})-p H_{0}\left(x_{i}\right)\right)
$$

where $p H_{0}(x), p H_{S},-$ random variables with mean values $\overline{p H_{0}}\left(x_{i}\right), \overline{p H_{s}}\left(x_{j}\right)$ and standard deviations $\sigma_{p H_{0}}, \sigma_{p H_{s}}$.

The measure of technological safety of tap water chemical stability on the example of the Langelier Index is a random function (8):

$$
Z(x)=p H_{0}(x)-p H_{s}(x)
$$
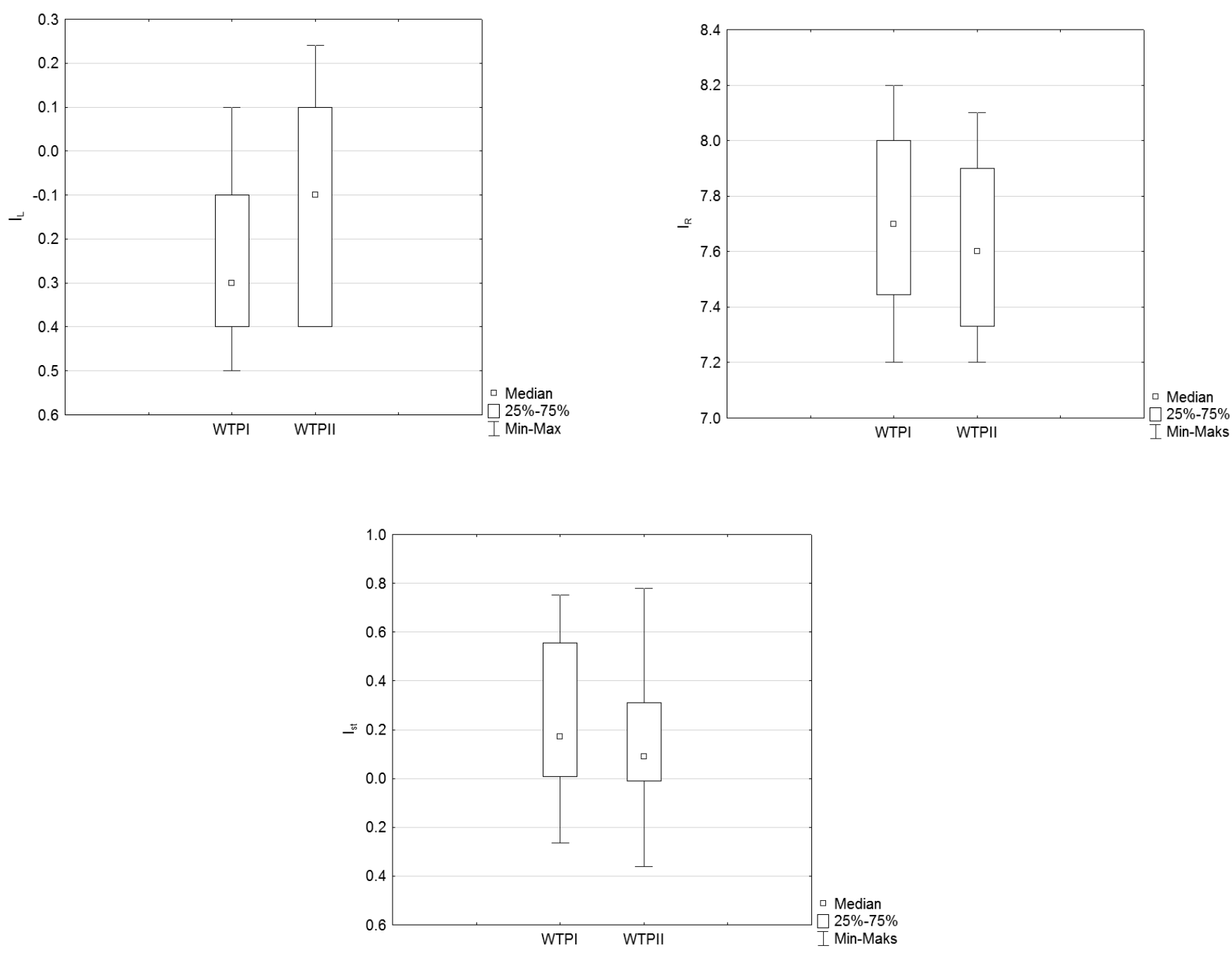

Fig. 1. Box plots for: a) the Langelier Index $\left(I_{L}\right)$, b) the Ryznar Index $\left(I_{R}\right)$ and c) the Strohecker Index $\left(I_{s t}\right)$ 


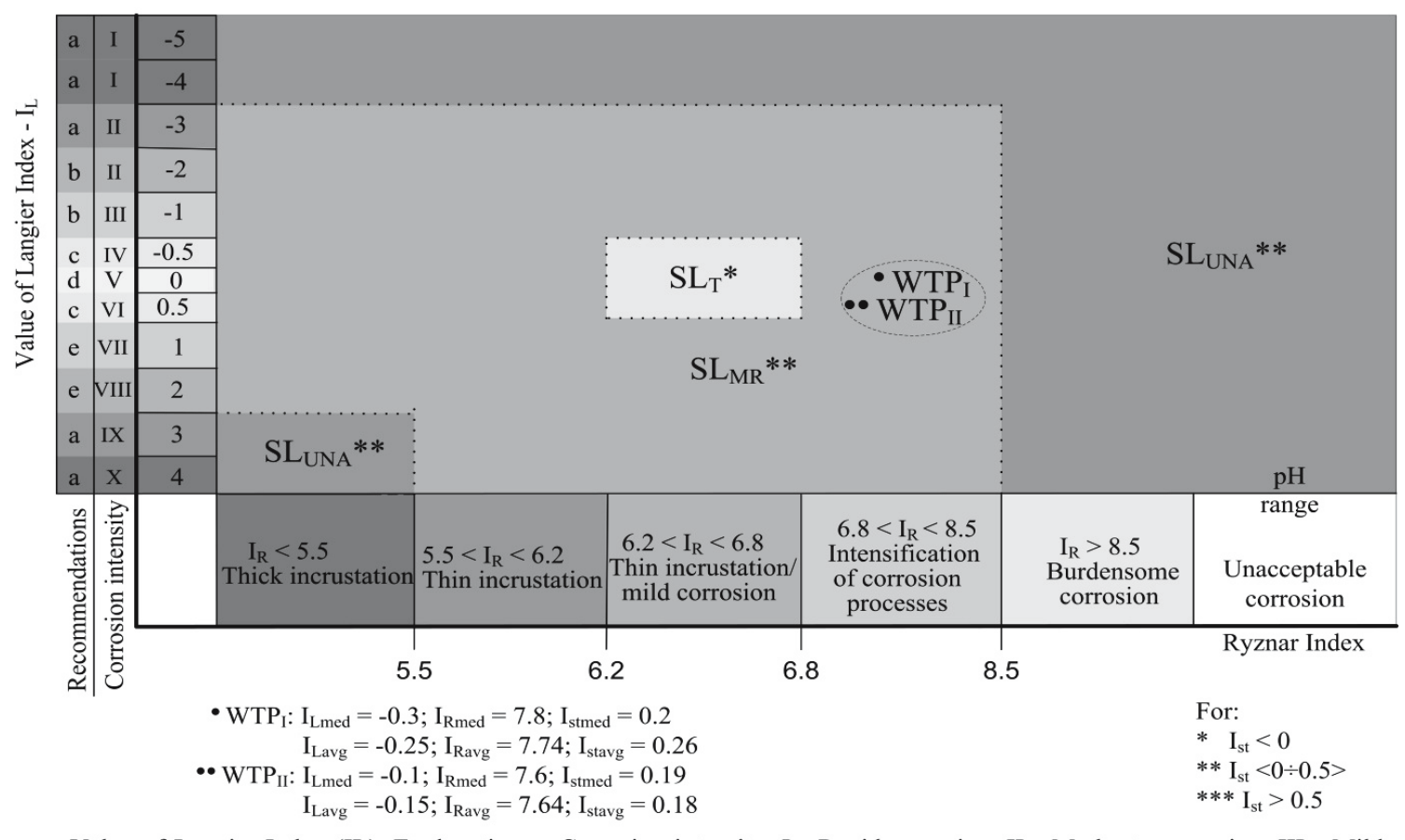

Value of Langier Index (IL), Explanations - Corrosion intensity: I - Rapid corrosion, II - Moderate corrosion, III - Mild corrosion, IV - Delicate corrosion, V - Carbonate balance, VI - Mild surface coating, VII - Delicate section reduction, VIII Gentle to moderate deposition of sediments, IX - Moderate deposition of sediments, X - The rapid deposition of calcium carbonate; Recommendations: a - Recommended treatment, b - Required treatment, c - There is probably no need for treatment, $\mathrm{d}$ - Treatment is not necessary, e - Treatment may be needed

Fig. 2. The situation in distinguished water supply system in terms of corrosive indices and safety levels

Function $Z(x)$ is called a function of the boundary condition (Nowak and Collins 2013).

The average value of the random function $Z$ is given by formula (9):

$$
\bar{Z}(x)=\overline{p H_{0}}(x)-\overline{p H_{s}}
$$

The standard deviation is determined by the dependence (10):

$$
\sigma_{Z}=\sqrt{\sigma_{p H_{0}}{ }^{2}+{\sigma_{p H_{S}}}^{2}}
$$

and the safety Index $t_{n x}$ is described by the formula (11):

$$
t_{n z}=\frac{Z(x)}{\sigma_{Z}}
$$

The use of such procedure primarily requires determining a reliable value of the standard deviation of an indicator defining the chemical stability of water.

To assess technological safety of water chemical stability the Monte Carlo simulation was used, in the form of the following procedure:

- draw a sequence of independent random numbers for each random variable included in the safety analysis,

- calculate the values of adopted safety measure, regarded as the result of physical experiments,

- check if the individual values are in the area of safe or unsafe states,
- after $\mathrm{N}=10^{6}$ simulations, calculate the quotient of results contained in the particular areas by the total number of results,

- value of the quotient can be regarded as a measure of safety or its loss.

The assessment of technological safety of water chemical stability using the probabilistic method was performed for different previously mentioned indices defining the chemical stability of water and for two WTPs.

\section{For WTP,}

The stability of water specified by the Langelier Index for the input variables $\mathrm{pH}$ and $\mathrm{pH}_{\mathrm{n}}$ and the condition of limit state for the Langelier Index is shown in Figure 3.

As a result of the analysis, the following values of the probability that the threshold values for the Langelier Index will be exceeded were obtained (Fig. 3):

- $P\left(I_{L}=0\right)=0.011$ - tolerable risk,

- $P\left(-3<I_{L}<4\right)=\left\{\begin{array}{l}P\left(I_{L}<0\right)=0.665 \\ P\left(I_{L}>0\right)=0.324\end{array}=0.989\right.$

- controlled risk.

Analyses of risk occurrence according to the Ryznar Index $\left(I_{R}\right)$ including the input variables $p H$ and $p H_{n}$ and the condition of limit state for the Ryznar Index are shown in Figure 4.

The obtained values of the probability that the threshold values for the Ryznar Index will be exceeded are: $P\left(6.2<I_{R}<\right.$ $6.8)=0.000-$ tolerable risk; $P\left(I_{R}<8.5\right)=1.000-$ controlled risk and $P\left(I_{R}>8.5\right)=0.000$ - unacceptable risk. 
The obtained values of the probability that the threshold values for the Strohecker Index will be exceeded are: $P\left(I_{s t}<\right.$ $0.5)=0.000, P\left(I_{s t}>0.5\right)=1.000-$ controlled risk $($ Fig. 5).

\section{For WTP}

The obtained values of the probability that the threshold values for the Langelier Index will be exceeded are (Fig. 6):

- $P\left(I_{L}=0\right)=0.015$ - tolerable risk,

- $P\left(-3<I_{L}<4\right)=\left\{\begin{array}{l}P\left(I_{L}<0\right)=0.425 \\ P\left(I_{L}>0\right)=0.560\end{array}=0.985\right.$

- controlled risk.
Analysis of risk occurrence according to the Ryznar Index for the condition of limit state is shown in Fig. 7.

The obtained values of the probability that the threshold values for the Ryznar Index will be exceeded are: $P\left(6.2<I_{R}<\right.$ $6.8)=0.000-$ tolerable risk, $P\left(I_{R}<8.5\right)=0.987-$ controlled risk and $P\left(I_{R}>8.5\right)=0.013$ - unacceptable risk.

For the Strohecker Index the following probabilities were obtained: $P\left(I_{s t}<0.5\right)=0.000$ and $P\left(I_{s t}>0.5\right)=1.000$ - controlled risk (Fig. 8).

The probabilities of the exceeding of the individual parameters with assigned to them safety levels are shown in Table 3.

In the case of the Rynzar Index $P\left(I_{R}<8.5\right)$ and the Strohecker Index $P\left(I_{s t}>0.5\right)$ for the analysed water treatment

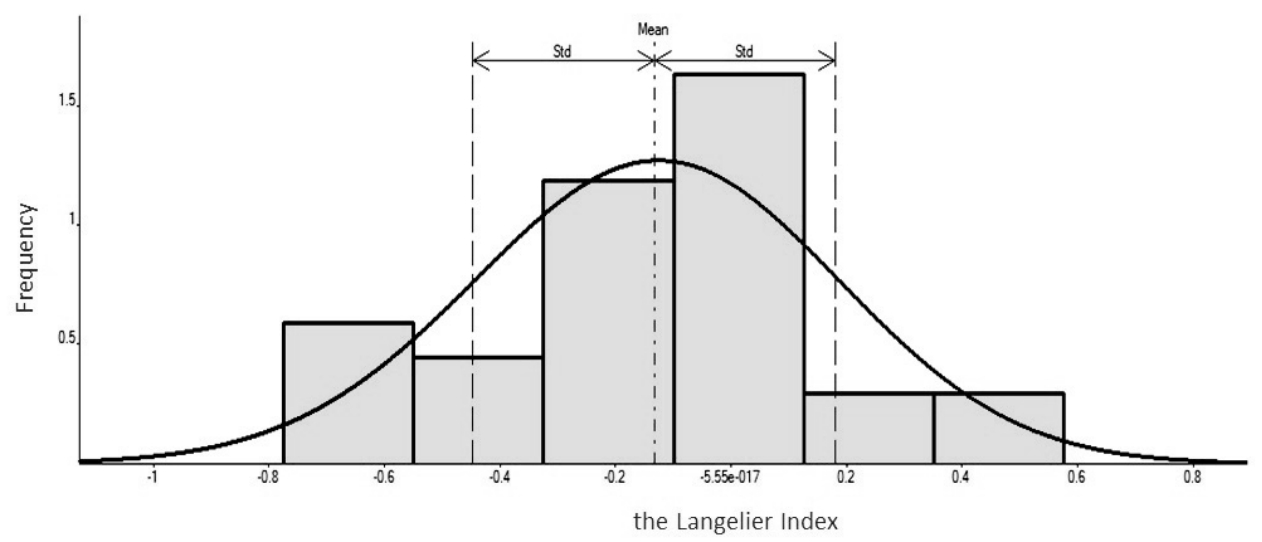

Fig. 3. Histogram and density function obtained for the condition of limit state defined for the Langelier Index - WTP $_{\text {, }}$

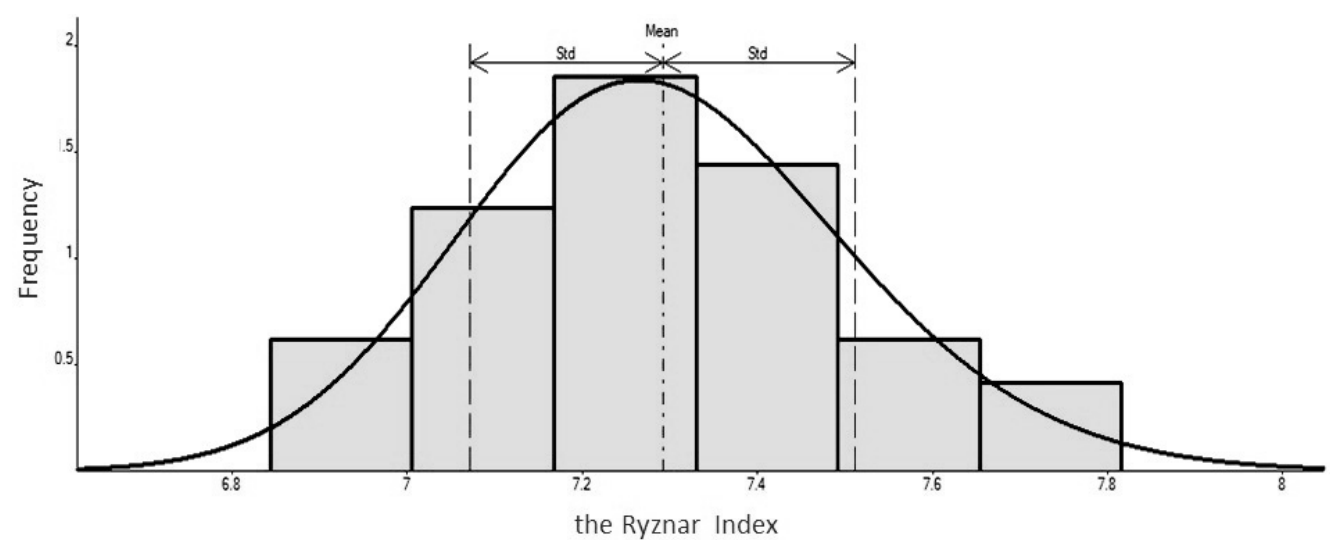

Fig. 4. Histogram and density function obtained for the condition of limit state defined for the Ryznar Index - WTP,

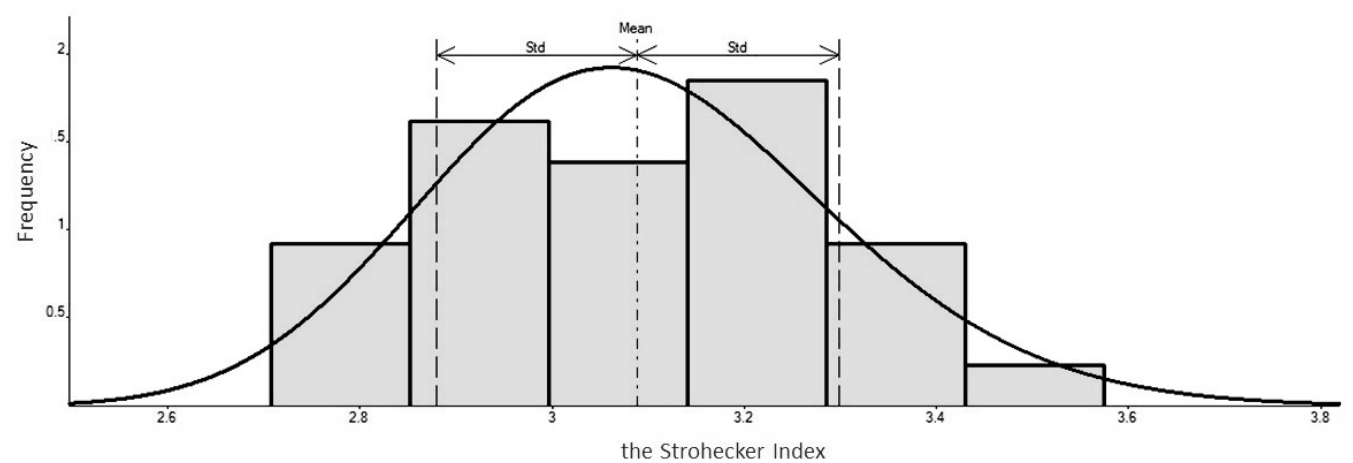

Fig. 5. Histogram and density function obtained for the condition of limit state defined for the Strohecker Index - WTP, 


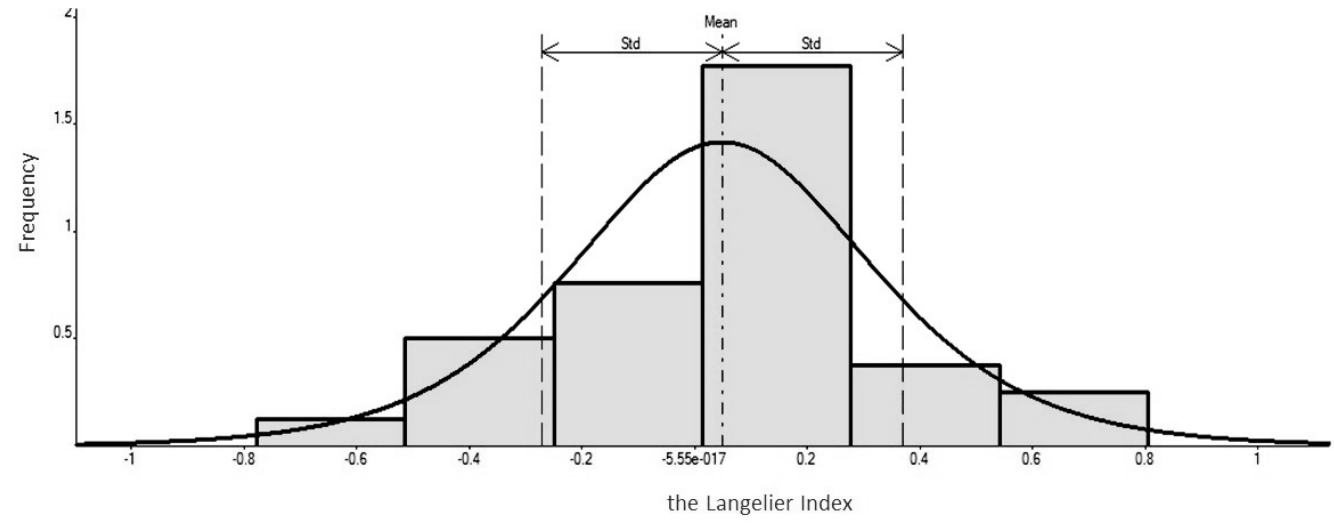

Fig. 6. Histogram and density function obtained for the condition of limit state defined for Langelier Index - WTP $_{\|}$

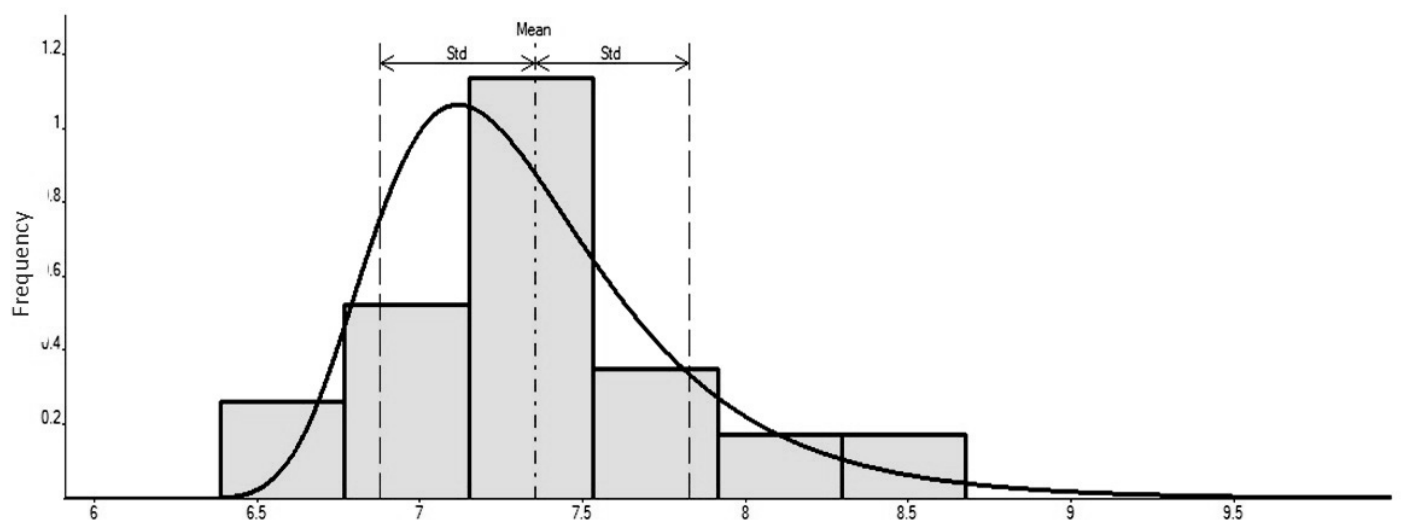

the Ryznar Index

Fig. 7. Histogram and density function obtained for the condition of limit state defined for the Ryznar Index - WTP

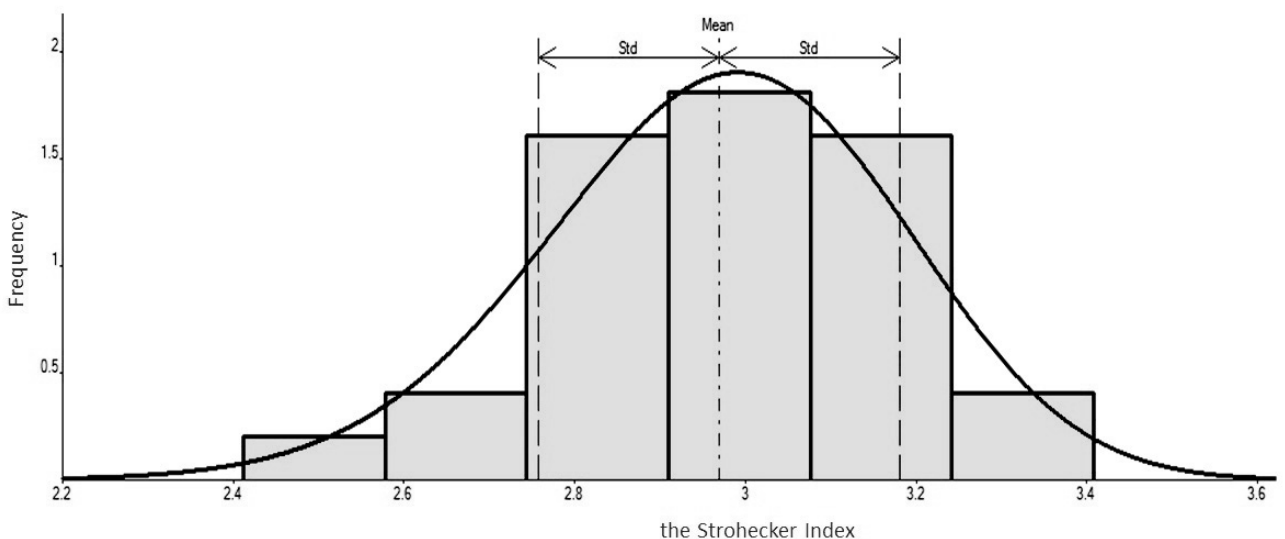

Fig. 8. Histogram and density function obtained for the condition of limit state defined for the Strohecker Index - WTP $_{\|}$

Table 3. The probabilities of the exceeding of the corrosiveness parameters together with the corresponding safety levels (SL)

\begin{tabular}{|c|c|c|c|}
\hline \multirow{2}{*}{ Specification } & $I_{L}$ & $I_{R}$ & $I_{s t}$ \\
\cline { 2 - 4 } & $\mathrm{P}\left(-3<\mathrm{I}_{\mathrm{L}}<4\right)$ & $\mathrm{P}\left(\mathrm{I}_{\mathrm{R}}<8.5\right)$ & $\mathrm{P}\left(\mathrm{I}_{\mathrm{S}}>0.5\right)$ \\
\hline \multirow{2}{*}{$\mathrm{WTP}_{\mathrm{I}}$} & 0.989 & 1,0 & 1,0 \\
\cline { 2 - 4 } & $\mathrm{S} \mathrm{L}_{\mathrm{RM}}$ & $\mathrm{SL}_{\mathrm{RM}}$ & $\mathrm{SL}_{\mathrm{RM}}$ \\
\hline \multirow{2}{*}{ WTP $_{\text {II }}$} & 0.985 & 0.987 & 1.0 \\
\cline { 2 - 4 } & $\mathrm{SL}_{\mathrm{RM}}$ & $\mathrm{SL}_{\mathrm{RM}}$ & $\mathrm{SL}_{\mathrm{RM}}$ \\
\hline
\end{tabular}


process $\left(\mathrm{WTP}_{\mathrm{I}}\right)$ the probability of the exceeding is $100 \%$, which corresponds to the safety level that requires modification. Similar situation exists for the Langelier Index where the probability of the exceeding for $P\left(-3<I_{L}<4\right)$ is $98,9 \%\left(\mathrm{SL}_{\mathrm{RM}}\right)$ and for $P\left(I_{L}=0\right)$ the probability of exceeding defines $1.1 \%$ of tolerable risk occurrence.

The detailed analysis showed that for technological water process for $\mathrm{WTP}_{\mathrm{II}}$ for the Langelier Index the probability of the exceeding for $P\left(-3<I_{L}<4\right)$ is $98.7 \%$, which corresponds to controlled risk, while considering the Ryznar Index for WTP $_{\text {II }}$ with $1.3 \% P\left(I_{R}>8,5\right)$ we can expect unacceptable risk occurrence.

The probability of the exceeding of the individual parameters for $\mathrm{WTP}_{\mathrm{I}}$ is slightly larger than for $\mathrm{WTP}_{\mathrm{II}}$, which means that this water treatment process may cause lack of chemical stability in the water supply network.

\section{Discussions and remedies}

In the case of tolerable risk level occurrence it is recommended to further monitor and maintain the current level associated with drinking water quality.

In the case of receiving the unacceptable risk level it is recommended to change the process by correlation to the hydraulic conditions and using the appropriate materials for the construction of water supply systems and internal installations.

Operators should anticipate in the process of designing water distribution system, with regard to using proper materials, as to ensure an adequate level of safety from the water source to the water recipient. It should be noted that it is necessary to adjust the material of internal installation of water supply network to the parameters of water and not the other way round. At present there is no correlation between the designing step and water parameters.

It should be indicated that such analysis should be made after examining water pipes materials. Also corrosion criteria and the type of corrosion that can occur in correlation with the quality of water should be determined. It should be noted that in each case corrosive criteria must be adjusted to the specific case of water distribution system.

\section{Conclusions}

It should be remembered that water of good quality according to the obligatory regulations can have corrosive and unstable character generating economic losses.

Except water quality, the condition of water pipes is influenced by prevailing hydraulic conditions as well as the material of pipes and fittings and its technical condition.

The quality of tap water intended for human consumption can be provided by use of appropriate materials for the construction of water supply network. Such materials should not be susceptible to corrosion, should prevent any pollution of potable water and protect water consumers, as well as ensure adequate stability of water supply.

To contribute towards safety of water consumers, the methodology presented in the paper should be applied in the daily functioning of water distribution system, in cooperation between engineers and operators.

\section{References}

Carneiro, RN., Damiao, S. \& Benoliel, M.J. (2015). Water safety plans at EPAL's water supply system-tool to prioritize investments and mitigation actions, Water Science Technology, 15, pp. 1106-1114.

Carrier Air Conditioning Company (1965). Handbook of Air Conditioning System Design, McGraw-Hill Books, New York 1965.

Darvishi, G., Kootenaei, F.G., Ramezani, M., Lotfi, E. \& Asgharnia, H. (2016). Comparative Investigation of River Water Quality by OWQI, NSFWQI and Wilcox Indexes (Case study: the Talar River - IRAN), Archives of Environmental Protection, 42, pp. 41-48. DOI: 10.1515/aep-2016-0005

Dubiel, M., Hsu, C.H., Chien, C.C., Mansfeld, F. \& Newman, D.K. (2002). Microbial iron respiration can protect steel from corrosion, Applied Environment Microbiology, 68, pp. 1440-1445.

EN 12502:2006 Guidance on the assessment of corrosion likelihood in water distribution and storage systems.

Ferrandez-Gamot, L., Busson, P., Blesa, J., Tornil-Sin, S., Puig, V., Eric, D. \& Soldevila, A. (2015). Leak localization in water distribution networks using pressure residuals and classifiers original, Water Resources, 48, pp. 220-225.

Garboś, S. \& Święcicka, D. (2015). Human health risk assessment of uranium in drinking water sampled from drilled wells located in rural areas of the Lower Silesian region (Poland), Archives of Environmental Protection, 41, pp. 21-27. DOI: 10.1515/aep-2015-0014

Gerke, T.L., Maynard, J.B., Schock, M.R. \& Lytle, D.L. (2008). Physiochemical characterization of five iron tubercles from a single drinking water distribution system: possible new insights on their formation and growth, Corrosion Science, 50, pp. 2030-2039.

Gorka, A., Papciak, D., Zamorska, J. \& Antos, D. (2008). The influence of biofilm on the effectiveness of ion exchange process, Industrial \& Engineering Chemistry Research, 47, pp. 7456-7464.

Haibo, W., Chun, H. \& Xiaoxiao, L. (2015). Characterization of biofilm bacterial communities and cast iron corrosion in bench-scale reactors with chloraminated drinking water, Engineering Failure Analysis, 57, pp. 423-433.

Husband, P.S. \& Boxall, J.B. (2011). Asset deterioration and discolouration in water distribution systems, Water Resources, 45, pp. 113-124.

Kaźmierczak, B. \& Wdowikowski, M. (2016). Maximum rainfall model based on archival pluviographic records - case study for Legnica (Poland), Periodica Polytechnica Civil Engineering, 60(2), pp. 305-312. DOI: 10.3311/PPci.8341

Królikowska, J. (2011). Application of PHA method for assessing risk of failure on the example of sewage system in the city of Krakow, Rocznik Ochrona Srodowiska, 13, pp. 693-710.

Kutylowska, M. \& Orlowska-Szostak, M. (2016). Comparative analysis of water-pipe network deterioration-case study, Water Practice and Technology, 11(1), pp. 148-156.

Kiedryńska, L., Papciak, D. \& Granops, M. (2006). Sanitary Chemistry, Warsaw University of Life Sciences - SGGW (WULS-SGGW), Warsaw 2006. (in Polish)

Lia, X., Wanga, H., Hua, C., Yanga, M., Hub, H. \& Niuc, J. (2014). Characteristics of biofilms and iron corrosion scales with ground and surface waters in drinking water distribution systems, Corrosion Science, 90, pp. 331-339.

McNeill, L.S. \& Edwards, M. (2001). Iron pipe corrosion in distribution systems, Journal of American Water Works Association, 93, pp. 88-100.

Langelier, W.F. (1936). The analytical control of anti-corrosion water treatment, Journal of the American Water Works Association, 28, pp. $1500-1521$.

Nowacka, A., Wlodarczyk-Makula, M., Tchorzewska-Cieslak, B. \& Rak, J. (2016). The ability to remove the priority PAHs from water during coagulation process including risk assessment, Desalination Water Treatment, 57, pp. 1297-1309. 
Nowak, A.S. \& Collins, K.R. (2013). Reliability of Structures, Taylor \& Francis Group, New York 2013.

Ondrejka-Harbulakova, V., Purcz, P., Estokova, A., Luptakova, A. \& Repka, M. (2015). Using a statistical method for the concrete deterioration assessment in sulphate environment, Chemical Engineering Transaction, 43, pp. 2221-2226.

Pietrzyk, A. \& Papciak, D. (2016). Organic Matter in Natural Water - Forms of Occurring and Methods of Purifying, Czasopismo Inżynierii Ladowej, Środowiska i Architektury - Journal of Civil Engineering, Environment and Architecture, JCEEA, 63 (2/I), pp. $241-252$. DOI: $10.7862 /$ rb.2016.126

Radzka, E., Rymuza, K. \& Jankowska, J. (2015). The assessment of drinking water quality using zero unitarization method, Archives of Environmental Protection, 41, pp. 91-95. DOI: 10.1515/aep-2015-0043

Ryznar, J. (1944). A new index for determining the amount of calcium carbonate scale formed by a water, Journal of the American Water Works Association, 36, pp. 472-486.

Strohecker, R. (1936). A New Way to Determine the Aggressiveness of Water, Zeitschrift für Analytische Chemie, 107, pp. 321-328. (in Deutsch)

Studziński, A. \& Pietrucha-Urbanik, K. (2015). Preventive maintenance and reliability of water supply system elements, Czasopismo Inżynierii Ladowej, Środowiska i Architektury - Journal of Civil Engineering, Environment and Architecture, JCEEA, 62(3), pp. 429-436. DOI: $10.7862 / \mathrm{rb} .2015 .126$
Suna, H. \& Wanga, X. (2016). $\mathrm{NH}_{4}^{+}$adsorption and adsorption kinetics by sediments in a drinking water reservoir, Archives of Environmental Protection, 42, pp. 90-95. DOI: 10.1515/aep-2016-0039

Tchórzewska-Cieslak, B. \& Szpak, D. (2015). Proposed method of analysis and assessment of water supply safety, Ochrona Środowiska, 37(3), pp. 43-47. (in Polish)

Tchorzewska-Cieslak, B. \& Rak, J. (2009). Method of identification of operational states of water supply system, Conf. Proc. of $3^{\text {rd }}$ Congress Environmental Engineering, Lublin, Poland, pp. 521-526.

Tchorzewska-Cieslak, B., Boryczko, K. \& Eid, M. (2012). Failure scenarios in water supply system by means of fault tree analysis, Advances in Safety, Reliability and Risk Management - Proceedings of the European Safety and Reliability Conference, ESREL 2011, pp. 2492-2499.

Volk, C., Dundore, E., Schiermann, J. \& Lechevallier, M. (2000). Practical evaluation of iron corrosion control in a drinking water distribution system, Water Resources, 34, pp. 1967-1974.

Zhang, H., Tian, Y., Wan, J. \& Zhao, P. (2015). Study of biofilm influenced corrosion on cast iron pipes in reclaimed water, Applied Surface Science, 357, pp. 236-247.

Zhang, Y., Griffin, A. \& Edwards, M. (2010). Effect of nitrification on corrosion of galvanized iron, copper, and concrete, Journal of American Water Works Association, 102, pp. 83-93.

\section{Analiza stabilności chemicznej wody wodociągowej pod kątem wymaganego poziomu bezpieczeństwa technologicznego}

Streszczenie: Głównym celem pracy jest przedstawienie nowego podejścia do określania poziomów technologicznych bezpieczeństwa (SL) w zakresie jakości wody i jej stabilności chemicznej, a także właściwości korozyjnych wody w systemach dystrybucji wody (WDS), ze względu na fakt, iż przewody wodociągowe są podatne na korozję. W pracy przedstawiono metodologię określania ryzyka związanego z wystąpieniem zagrożeń dla infrastruktury technicznej. Analiza została wykonana na podstawie uzyskanych danych eksploatacyjnych ze stacji uzdatniania wody. Prawdopodobieństwo przekroczeń poszczególnych parametrów w przypadku WTPI jest nieznacznie większe od WTPII, co oznacza iż ten proces uzdatniania wody może powodować brak zachowania stabilności chemicznej w sieci wodociągowej. Operatorzy powinni przewidzieć w procesie projektowania systemu dystrybucji wody, użycie odpowiednich materiałów, tak aby zapewnić odpowiedni poziom bezpieczeństwa od źródła wody do odbiorcy. Należy zauważyć, że niezbędne jest dostosowanie materiału wewnętrznej instalacji sieci wodociągowej do parametrów wody nie odwrotnie. W chwili obecnej nie ma korelacji pomiędzy etapem projektowania, a parametrami wody. W celu ochrony infrastruktury wodociągowej, które należą do infrastruktury krytycznej, przedsiębiorstwo wodociągowe powinna położyć większy nacisk na dystrybucję stabilnej wody, która nie ma właściwości korozyjnych. W pracy zaproponowano podjęcie działań zapewniających ochronę systemu dystrybucji wody przed utratą stabilności chemicznej wody. 